\title{
短周期微動に含まれるレイリ一波の特性と地盤構造の関係 CHARACTERISTICS OF RAYLEIGH WAVES IN MICROTREMORS AND THEIR RELATION TO UNDERGROUND STRUCTURES
}

\author{
時松孝次*, 宮寺泰生** \\ Kohji TOKIMATSU and Yasuo MIYADERA
}

\begin{abstract}
Short-period microtremors are observed at two sites using arrays. It is found that their variation with frequency of amplitude ratio between horizontal and vertical motions is stable during a 24hour period and is similar to that of Rayleigh waves, and that the frequencies at which the amplitude ratio becomes the maximum correspond to the natural periods of the sites. The frequencywavenumber spectrum analysis of microtremor vertical motions yields Rayleigh wave dispersion curves which reflect the shear structures of the sites. These findings suggest that site effects can be reliably estimated by extracting Rayleigh wave characteristics from microtremors.
\end{abstract}

Keywords : short-period microtremors, shear wave velocity, Rayleigh wave, geophysical exploration, natural site period, array observation 短周期微動, $S$ 波速度, レイリ一波, 物理探査, 地盤の固有周期, アレイ観測

\section{1. 序 論}

微動は地表で時間を選ばず観測でき，しかも地盤特性 に関する情報を含んでいるため,これを利用した地盤調 查法が古くから研究されている。金井, 田中“' 秒程度以下の短周期微動が $S$ 波の重複反射によるもの であると考え，1点で観測された微動のスペクトル解析 より求められる卓越周期等に基づいて地盤種別を推定す る方法を提案した。以後, この方法は常時微動測定と呼 ばれ短周期微動を利用した調査の中で，最も一般化され たものとなっている。しかし，短周期微動の周期特性は 観測点の地盤特性に加えて周辺の振動源特性をも反映す るため, 微動の卓越周期が地盤の固有周期と対応しない 場合がある2)。ぞのため, 常時微動測定の有効性に関し ては意見の分かれるところである。

振動源の特性が測定結果に与える影響を軽減するた め, 中村, 上野 ${ }^{31}$ は, 1 点で観測された微動の水平鉛直 振幅比の周期特性加ら地盤の固有周期を推定する方法を 提案している。そして，その妥当性は，金井，田中の研 究”の場合之同様, 短周期微動が $S$ 波の重複反射による ものであると仮定して説明されている。しかし，一方で は, 短周期微動には表面波が卓越していることを示唆す
る報告4) 7)もある。

Allam，鴆 ${ }^{31}$ は，地表と基盤とのコントラストが明暸 な地点では，微動を実体波または表面波あるいは両者か らなるもののいずれとして取扱っても，卓越周期に関す る限り違いが無いことを示している。しかし，短周期微 動の波動的性質については現在まで未解明の部分があ る。

周期約 1 秒以上の長周期微動に対しては, アレイ観測 等から, 表面波（レイリー波とラブ波）が優勢であるこ

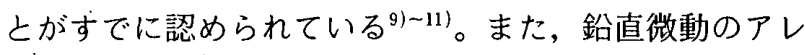
亿観測に基づきレイリー波のものと考えられる分散特性 を求め, その逆解析から地盤の $S$ 波速度構造を推定し た例 ${ }^{12) .13)}$ もある。レイリ一波の分散特性は地盤固有のも ので振動源の周期特性に影響されないため,このように 地盤構造の推定が可能となる。近年, 短周期微動に対し ても同様の試みが報告されている(4),15)。これらの報告の ように微動からレイリー波の特性が常に抽出できるなら ば, より信頼性の高い地盤特性の把握が可能になる。 そこで, 本研究では短周期微動に含まれる表面波成分 の工学的利用法に関する基礎的研究として，2地点で一 昼夜にわたる連続アレイ観測を行い，短周期微動に含ま

\footnotetext{
* 東京工業大学工学部建築学科 助教授 - 博士 (工学) Assoc. Prof., Dept. of Archịtecture and Building Engineering, Facul-. ty of Engineering, Tokyo Institute of Technology, Dr. Eng.

** 東京工業大学工学部建築学科 大学院生. 修士 (工 Graduate Student, Dept. of Architecture and Building Engineering, 学) Faculty of Engineering, Tokyo Institute of Technology, M. Eng.
} 
れるレイリー波成分の抽出を試み，短周期微動から振動 源の影響を除去して地盤特性を推定する可能性について 検討する。

\section{2. 短周期微動の連続アレイ観測}

\section{1 測定地点の特性}

2 地点で一昼夜にわたる短周期微動のアレイ観測を 行った。測定地点は，東京湾の台場（以下サイトAと呼 ぶ）と，東京工業大学緑が丘グランド（以下サイト B と 呼ぶ）である。サイトAの南東側には首都高速道路が通 り，昼夜とも交通量が多い。さらに同方角では建設工事 が行われており，日中は建設用重機が運転され，振動レ ベルが高い。しかしそのほかには人工的振動源はほとん どない。また周囲を海に囲まれ海岸が非常に近い。サイ トBの北側および東側には校舎および実験棟がある。周 辺は閑静な住宅街であるが，南側遠方に東急目蒲線と大 井町線が走り，西側そばを道路が通る。

標準貫入試験および PS 検層より求めた各サイトの地 盤構造を図一 1,2 に示す。サイトA $S$ 波速度 $150 \mathrm{~m} / \mathrm{s}$ 程度の沖積粘土層が深度 $30 \mathrm{~m}$ まで続き，その下に $S$ 波 速度 $300 \mathrm{~m} / \mathrm{s}$ 以上の洪積層がある。一方，サイト $\mathrm{B}$ は,

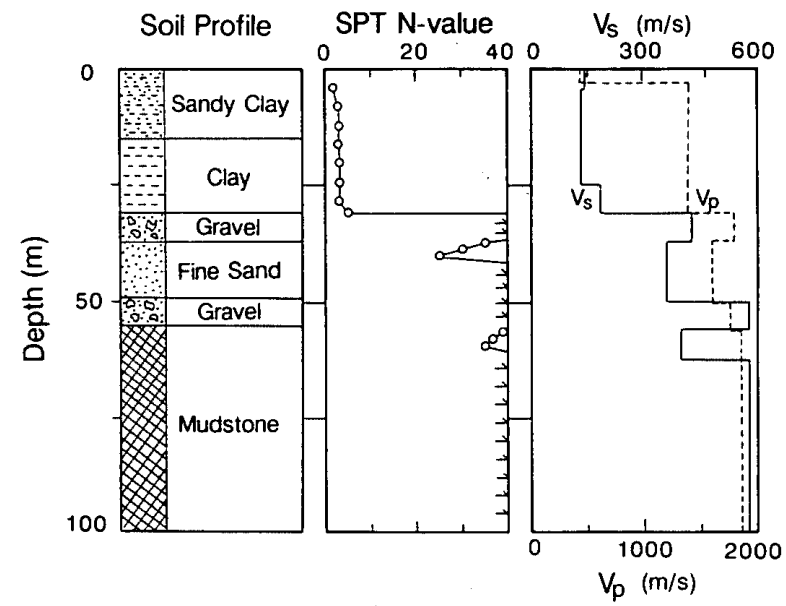

図一1 サイトAの地盤構造

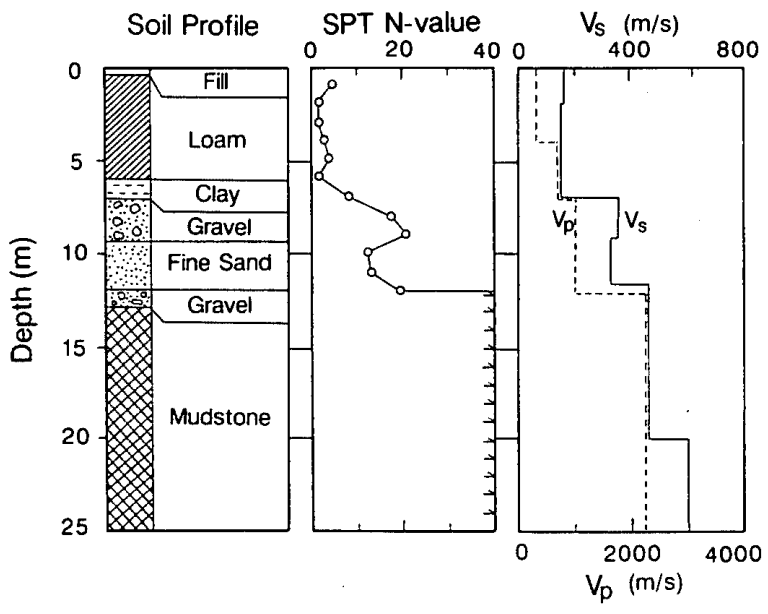

図一2 サイトBの地盤構造

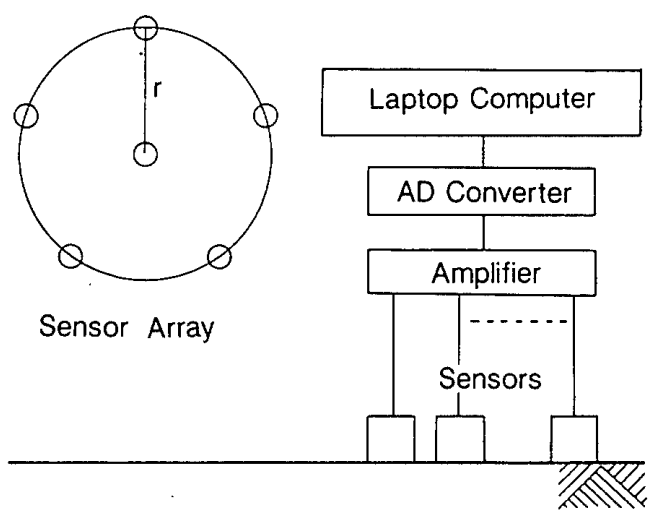

図一3 観測計器と観測アレイ

$S$ 波速度 $150 \mathrm{~m} / \mathrm{s}$ 程度の関東ローム層が表層に薄く堆積 し, 深度 $6 \mathrm{~m}$ 上り $S$ 波速度 $300 \mathrm{~m} / \mathrm{s}$ 以上の硬質な層とな る。両地点とも, 表層とその下にある硬質層とのコント ラストが比較的明瞭である。図に示す $S$ 波速度構造の 最下層 $(S$ 波速度約 $600 \mathrm{~m} / \mathrm{s})$ が半無限に続くものと仮 定して $S$ 波重複反射理論より求めたサイトAの 1 次固 有周期は約 1 秒， 2 次固有周期は約 0.35 秒，またサイ トBの固有周期は約 0.2 秒である。

\section{2 測定方法}

観測に用いた計器は，速度計およびローパスフィル夕 を組込んだ増幅器 (8チャンネル)，12ビット $\mathrm{AD}$ 変換 器とラップトップコンピュータである（図一3）。微動計 の総合特性は，約 1 秒以下で速度に対して平坦なもので ある。観測アレイは，水平 2 方向 $(N S, E W)$ および 鉛直方向 $(U D)$ の 3 成分速度計を観測点中心に固定し, その点を中心とする円周上に 5 個の鉛直成分速度計を等 間隔に配置したもの（図一3）である。

観測は一昼夜， 3 時間ごとに，サイトAでは半径 5 , 10, 20,30 mのアレイを, サイトBでは半径 2, 5, $10 \mathrm{~m}$ のアレイを組んで行った。アレイ半径の最大值は各地点 の敷地条件の制約によるものである。半径の異なるアレ イごとに, 数分ないし 10 分程度, 8 成分 (鉛直 6, 水平 2) の微動データを同時観測した。観測波形はローパスフィ ル夕 $(12.5 \mathrm{~Hz}$ または $25 \mathrm{~Hz},-12 \mathrm{~dB} / \mathrm{Oct})$ と增幅器 をとおして，サンプリング周波数 100 ～ $200 \mathrm{~Hz}$ 程度でデ ジタル化して,ラップトップコンピュータに取り込んだ。 この際，1成分につき 2048 ポイントを単位とする 8 な いし 16 個のデータファイルを作成して以後の解析に用 いた。

\section{3. 解析手法}

\subsection{3 成分測定に対する解析}

コンピュータに取り込んだ時間領域の微動データを フーリ工変換し，加算平均を行って $N S, E W, U D$ 成分 のフーリエスペクトルを求めた。加算平均された水平 2 成分のフーリエスペクトル振偪を次式で相乗平均して， 
水平動の平均スペクトル振幅 $S_{H}$ とする。

$$
S_{H}=\sqrt{S_{N S} S_{E w}}
$$

ここに, $S_{N S}, S_{E W}$ はそれぞれ $N S, E W$ 成分のフーリエ スペクトル振幅である。微動の水平鉛直振幅比 $(u / w)_{m}$ を，さらに次式で定義する。

$$
(u / w)_{m}=S_{H} / S_{u D}
$$

ここに， $S_{U D}$ は鉛直成分のフーリエスペクトル振幅であ る。

\section{2 アレイ観測データに対する解析}

アレイ観測された鉛直微動データに対して，F-K ス ペクトル解析を適用し, その位相速度を求めた。 $i$ 番目 の鉛直速度計が，座標ベクトル $x_{i}$ にあるとすれば，最 尤法による $F-K$ スペクトル, $\boldsymbol{P}(f, \boldsymbol{k})$, が次式で定義 できる ${ }^{16) 。}$

$$
\begin{gathered}
P(f, \boldsymbol{k})=\sum_{j, l=1}^{n} A_{j}^{*}(f, \boldsymbol{k}) A_{l}(f, \boldsymbol{k}) G_{j l}(f) \exp \\
\left\{i \boldsymbol{k} \cdot\left(\boldsymbol{X}_{j}-X_{\imath}\right)\right\} \ldots \ldots \ldots \ldots \ldots \ldots \ldots \ldots \ldots \ldots \ldots \ldots \ldots \ldots \ldots \ldots \ldots \ldots \ldots \ldots \ldots \ldots \ldots \ldots \ldots
\end{gathered}
$$

ここに,

$$
A_{j}(f, \boldsymbol{k})=\sum_{l=1}^{n} q_{j l}(f, \boldsymbol{k}) / \sum_{j, l=1}^{n} q_{j l}(f, \boldsymbol{k}) \cdots
$$

また， *は共役複素数を示し, $f$ は周波数, $n$ は鉛直速 度計の数, $\left\{q_{j l}\right\}$ は $\left\{\exp \left[i k \cdot\left(\boldsymbol{X}_{j}-\boldsymbol{X}_{l}\right)\right] G_{j l}\right\}$ の逆マトリッ クス, $G_{j l}$ は $j, l$ 番目のセンサーで観測される波形の加 算平均された正規化クロススペクトル，kは2次元波数 ベクトル $\left(k_{x}, k_{y}\right)$ で，単位は $\mathrm{rad} / \mathrm{m}$ である。

2 次元波数平面に描いたスペクトルがピークとなる波 数べクトルを $k_{\rho}$ とすれば, 位相速度 $c$ および波長 $\lambda$ が 次式で計算される。

$$
\begin{aligned}
& c=2 \pi f /\left|\boldsymbol{k}_{p}\right| \\
& \lambda=2 \pi /\left|\boldsymbol{k}_{\boldsymbol{p}}\right| \cdots
\end{aligned}
$$

各周波数に対して上記の操作を繰返し，位相速度と波長 の関係，すなわち分散特性を得る。

\section{4. 水平動および鉛直動スペクトル}

\section{1 サイトAにおける結果}

3 時間ごとに测定した水平動と鉛直動スペクトルを 24 時間分重水て図一 4,5 に示す。水平動スペクトル（図一 4)に昼夜とも卓越する周期約 1 秒と約 0.35 秒の成分は, それぞれ地盤の 1 次および 2 次の固有周期に対応してい る。1秒のピークは顕著な振幅の日変化を示し, 夜間 (21 時- -6 時) の振幅は昼間（9 時一 18 時）の $1 / 4$ 程度 となる。二方， 0.35 秒のピークは夜間でも昼間の $1 / 2$ 以上の振幅をもち，その日変化が比較的小さく，昼夜に かかわらず安定している。

鉛直動スペクトル（図一5）には水平動の 2 次の卓越 周期約 0.35 秒付近にピークが見られる。しかし，ビの 時刻においても 1 次卓越周期に対応する 1 秒の成分が ピークとなることはない。

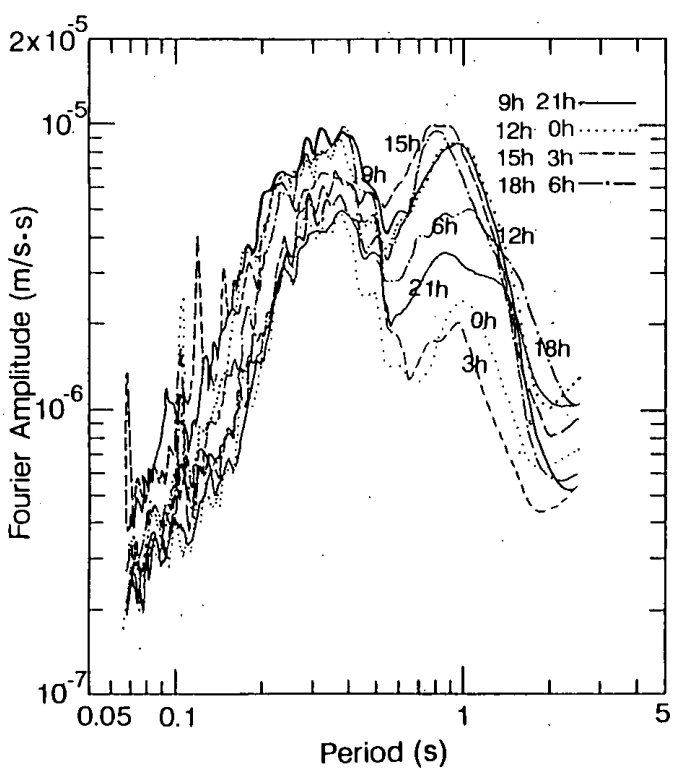

図一4 サイト Aの水平動スペクトルの日変化

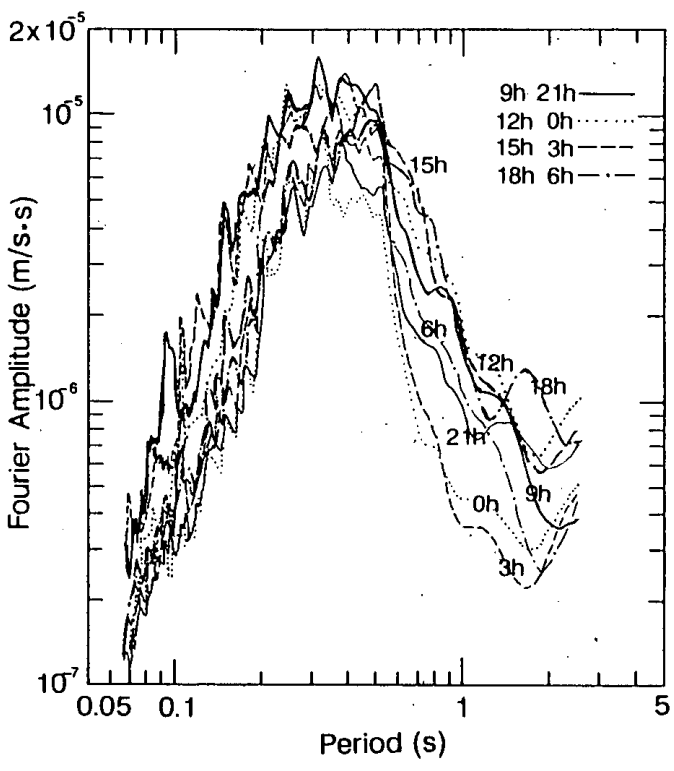

図一5 サイト Aの鉛直動スペクトルの日変化

\section{2 サイトBにおける結果}

サイトBにおいて 3 時間ごとに测定した水平動スペク トルと鈶值動スペクトルを図一6，7に示す。周期 0.2 秒以下および 1 秒以上でややスペクトル振幅の日変化が 認められるが，サイトAに比べその変化は相対的に小さ い。

水平動スペクトル（図一6）は約 0.2 秒から約 0.4 秒 が卓越しているが, 日中は 0.2 秒, 夜間は 0.4 秒のピ一 クがやや優勢である。日中のピークとなる 0.2 秒は地盤 の 1 次固有周期にほぼ対応しているが, 夜間にこの周期 を明確にとらえることは難しい。このことから，地盤条 件と測定時間によっては水平動スペクトルが最大となる 周期と地盤の固有周期が明確に対応しない場合のあるこ とが確認される。以上の現象は従来から指摘されてい る2)ように，微動が地盤固有の性質に加え，人間活動に ともなう振動の影響をも強く受けているためと考えられ 
る。また，サイト Aとサイト Bの比較から，その影響は 卓越周期の短い硬質地盤で顕著になる可能性のあること が示唆される。

一方，鉛直動スペクトル（図一7）には，夜間に水平 動スペクトルが最大となる周期約 0.4 秒に比較的明確な 山が見られる。しかし，昼間に水平動スペクトルが最大 となる周期 0.2 秒付近は, どの時刻においても谷となっ ている。

\section{3 水平鉛直振幅比}

図一4 7 サイト Bで 0.2 秒）付近では水平動の振幅が鉛直動の振 幅よりかなり大きく，それ以外の周期ではおよそ 1 対 1 となっている傾向が読取れる。そこで各測定地点の 3 時 間ごとの微動の水平鉛直振幅比の周期特性をまとめて図 一8, 9 に実線で示す。微動の水平鉛直振幅比の周囲特性

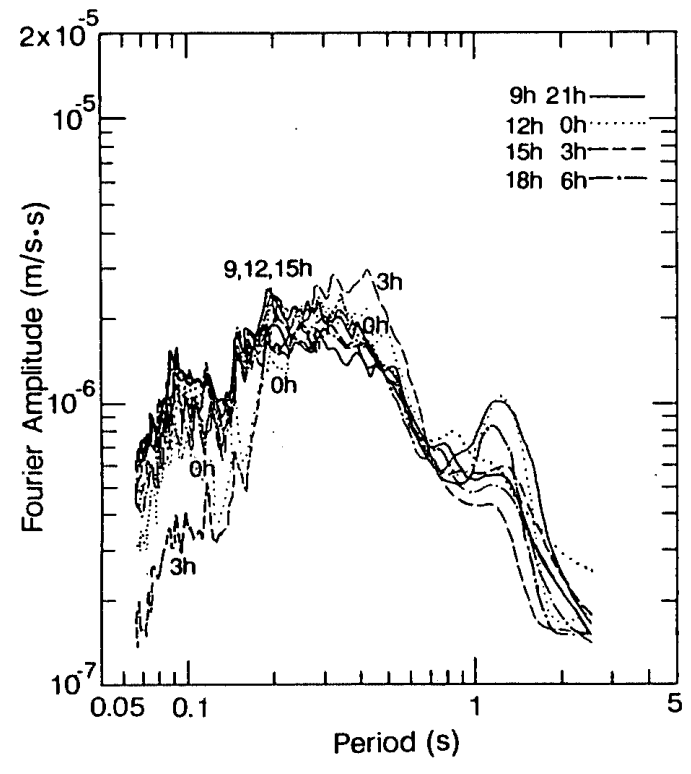

図一6 サイト Bの水平動スペクトルの日変化

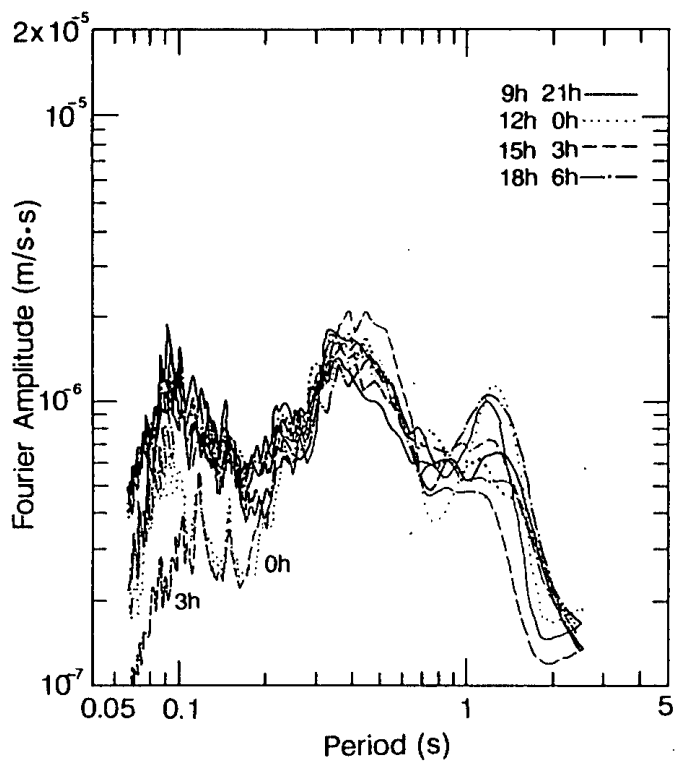

図一7 サイトBの鉛直動スペクトルの日変化
は，両サイトとも測定時刻にかかわらず極めて安定し， 日変化がない。したがって, 水平動のスペクトルよりも 水平鉛直振幅比の周期特性のほうが，振動源の影響が少 なく，地盤構造をより強く反映していると考えられる。 同様の現象は中村，上野泎によっても指摘されている。

図一8,9において水平鉛直振幅比が最大となる周期は サイトAで約 1 秒，サイトBで約 0.2 秒となり，日変化 がなく安定している。さらに，これらの周期は各サイト の地盤の 1 次固有周期にほぼ対応している。以上の結果 から，中村，上野3)が指摘しているように，水平鉛直振 幅比が最大となる周期から地盤の固有周期を推定できる 可能性が示唆される。

長周期微動に対しては，その水平鉛直振幅比の周期特 性に日変化が少なく，その原因が微動にレイリー波が含 まれているためであることが小林 ${ }^{17} に$ にり指摘されてい

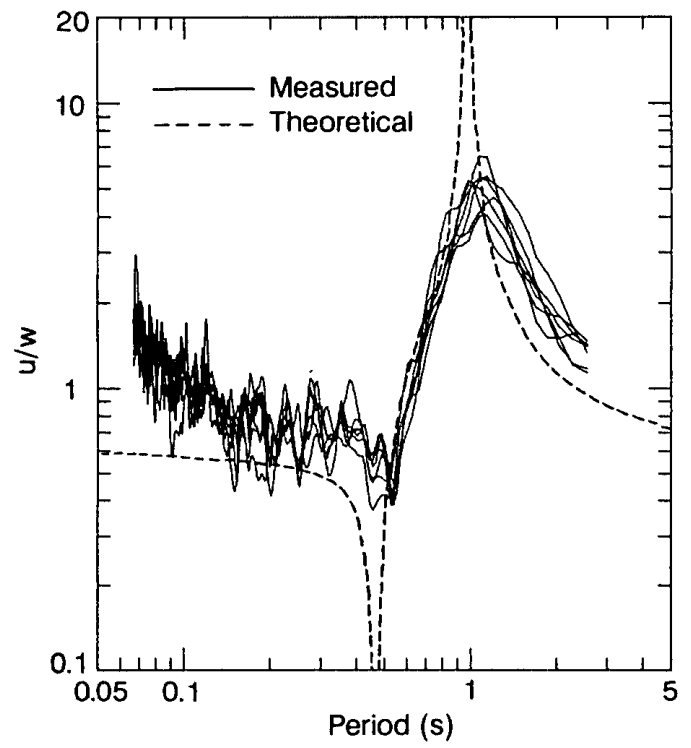

図一8 サイト Aの水平鉛直振幅比の観測と理論の比較

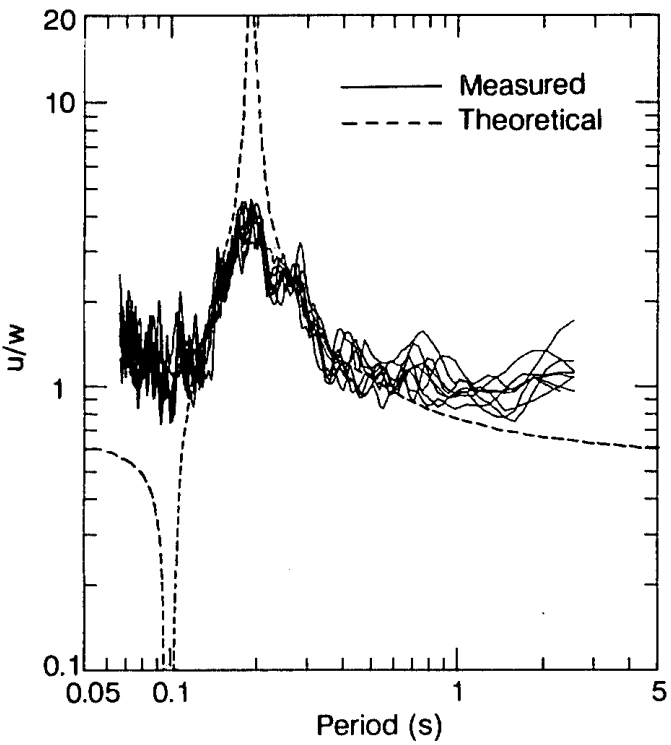

図一9 サイトBの水平鉛直振幅比の観測と理論の比較 
る。レイリー波は棈円形の軌跡を持ち, その水平動と鉛 直動の振幅比は振動源の影響を受けず地盤構造に依存し て決まる。したがって，短周期微動の水平動および鉛直 動それぞれの振幅が日変化しても，その比をとると一定 となるのは，微動にレイリー波が卓越しているためと考 えられる。

そこで，図一1，2に示す地盤構造からレイリー波基本 モードの水平鉛直振幅比をハスケルの理論 ${ }^{181} に$ 基づいて 求め, 図一 8,9 に破線で示す。理論振幅比の周期特性は 観測と全般的な傾向が良く一致し，その值が最大となる 周期も観測と良く対応している。理論と観測における振 幅比の整合性は，短周期微動にレイリー波が含まれてい ることを裏付けるものと考えられる。なお，理論と観測 においてその値が完全に一致しない理由には，レイリー 波以外の波の影響，高次モードレイリー波の影響，既往 の調査より求められた地盤構造の精度，理論において仮 定した水平成層構造の妥当性などが考えられるが，現状 では判断がつかない。

中村，上野31 は，短周期微動の水平鉛直振幅比の周期 特性が安定し，その値が最大となる周期が地盤の卓越周 期に対応している理由を， $S$ 波の増幅特性と関連づけ て説明している。しかし，本研究結果に基づけば，以上 の現象は，短周期微動にレイリ一波が卓越していること で，より明確に説明づけられると思われる。

\section{5. 鉛直動の分散特性}

短周期微動にレイリー波が卓越しているという前章の 結果を踏まえ，両サイトで 3 時間ごとに観測された微動 のアレイ観測記録に対し $F-K$ スペクトル解析を行っ て, 鉛直成分の分散特性を求めた。この際, 結果の信頼 性を考慮して，鉛直動のスペクトル振幅がその最大振幅 のおおむ称 $1 / 10$ 以上ある周波数帯を解析対象とした。

図一10，11 はサイトAおよびサイトBにおいて日中に 観測された微動に対する解析結果を，それぞれ 4 種類の 周波数に対して示したものである。解析より求められた $F-K$ スペクトルは，2 次元波数平面上 $\left(k_{x}, k_{y}\right)$ に，その 最大值から $2 \mathrm{~dB}$ ごとに $12 \mathrm{~dB}$ まで等高線で示してい る。なお，図の*はスペクトルの最大值を示し，図の上 が北に対応する。

サイト、Aにおけるスペクトル（図一10）の最大值が, いずれの周波数においても原点（各図の中心）の右下方 にあることから，微動が主として南東より伝播している ことが分かる。これはその方角にある高速道路を通行す る車両および建設工事にともなう振動が微動の主たる振 動源となっているためと考えられる。一方，サイトBの スペクトル（図一11）が最大值となる方角は各周波数ご とに一定でない。これは，このサイトにおける微動の振 動源が，サイトAに比べて一定の方角に集中していない
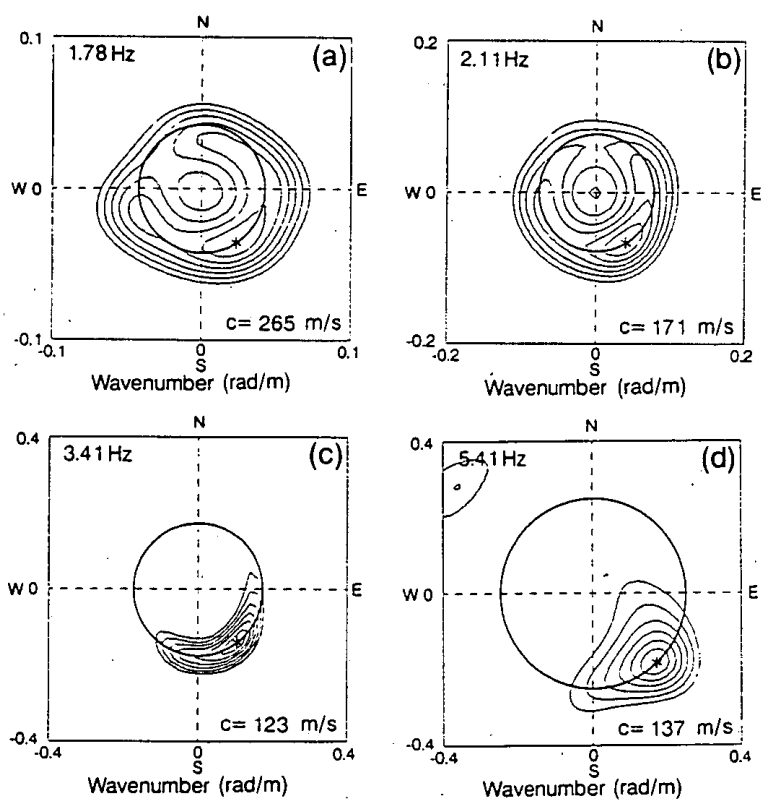

図一10 サイトAの $F-K$ スペクトル例（12 時）
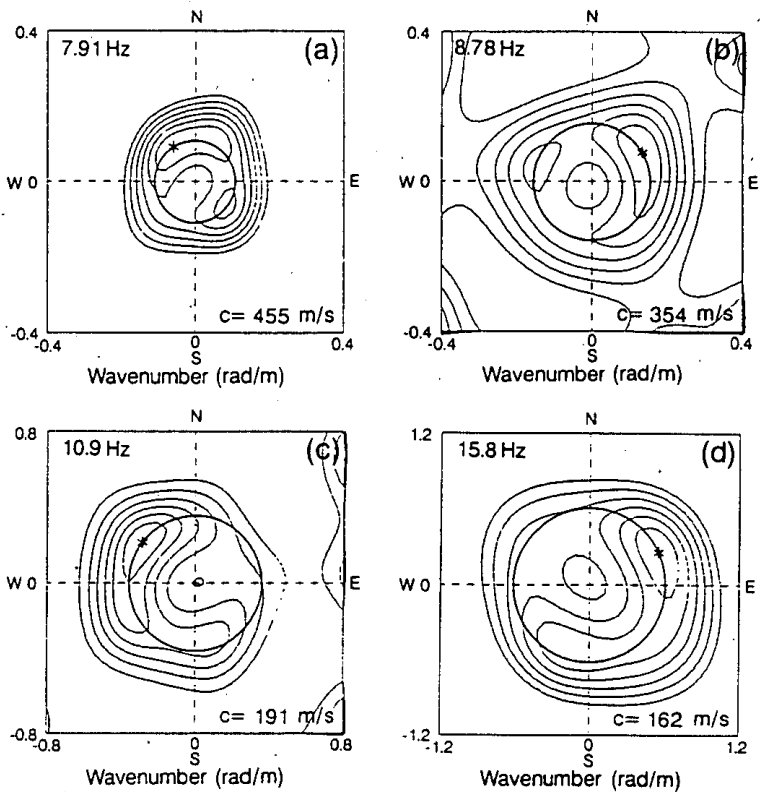

図一11 サイトBの $F-K$ スペクトル例（15 時)

ためと思われる。

図一 12,13 は両サイトで 3 時間ごとに求められた分散 特性をそれぞれ比較したものである。異なるアレイ半径 より得られた微動の $F-K$ スペクトル解析から求められ た分散特性は，波長がアレイ半径の約 2 から 6 倍程度の 範囲でほぼ連続するものであった。したがって, サイト $\mathrm{A}$ では波長約 $180 \mathrm{~m}$ 以下（約 $1.7 \mathrm{~Hz}$ 以上），サイトBで は波長 $60 \mathrm{~m}$ 以下（約 $7 \mathrm{~Hz}$ 以上）に対して分散特性を示 した。

図一 12,13 から，両サイトで得られた鉛直微動の周波 数特性が日変化しているにもかかわらず，その分散特性 は日変化がなく安定していることが分かる。このことは， 測定された分散特性が，水平鉛直振幅比と同様，振動源 の日変化に依存せず，地盤固有の特性を反映したもので 

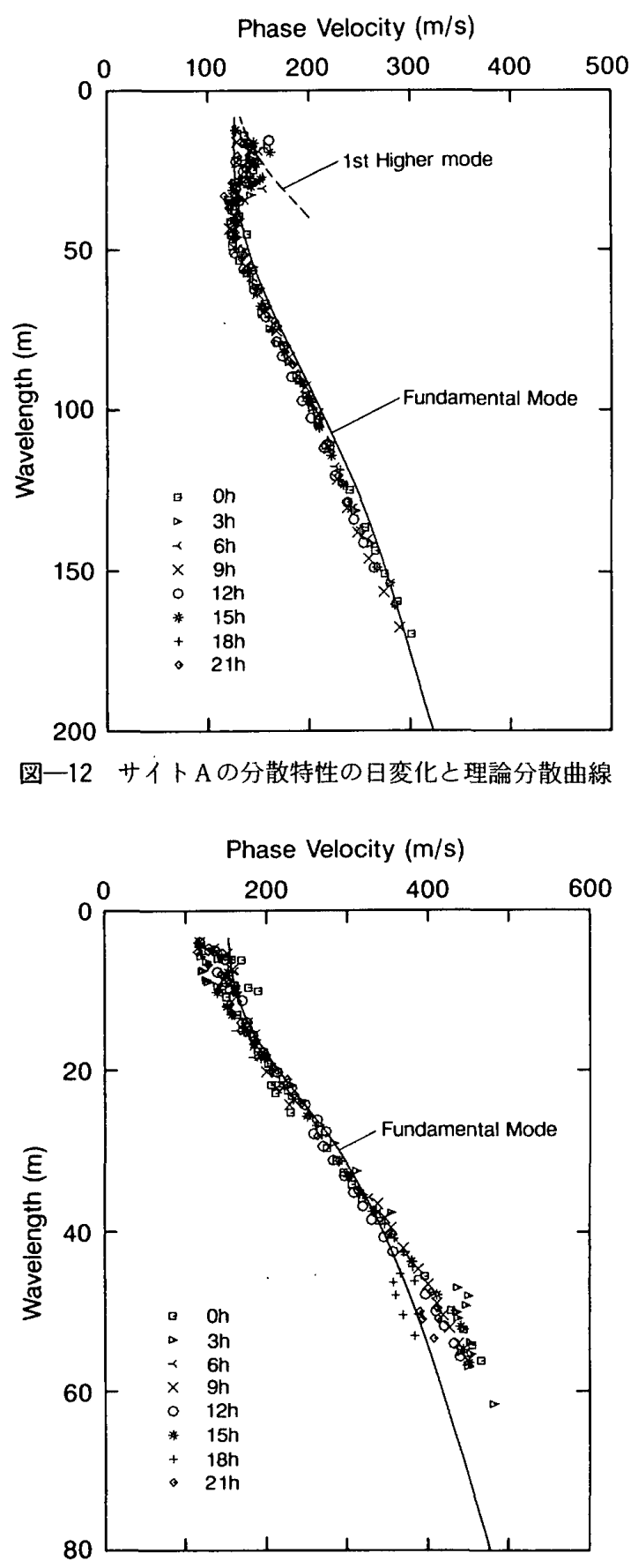

图一13 サイトBの分散特性の日変化と理論分散曲線

あることを示唆している。

そこで, 図一1，2 の地盤構造に対するレイリ一波基本 モードの分散特性をハスケルの理論 ${ }^{18}$ に基づいて求め, 図一12，13 に実線で示す。なお，サイトAの波長 $30 \mathrm{~m}$ 以下では，やや逆分散の傾向を示し，高次モードの存在 が示唆される。そこで,この部分に対しては, 1 次高次 モードの理論分散特性も破線で示した。微動の $F-K$ ス ペクトル解析より求められた分散特性は, レイリー波の 理論分散特性と比較的良い対応があり，観測された周期 領域における微動の鉛直成分にレイリー波が卓越してい ることが確認される。

サイトBの結果では, 夕方から早朝にかけて微動の振
幅が相対的に低下するため分散特性がばらつく周波数帯 があるが，それ以外の時間において求められた分散特性 は安定している。このことより，対象とする周波数帯に おける微動のパワーが十分ならば安定した分散特性が抽 出できる可能性が示唆される。

短周期微動の観測からレイリー波分散曲線が抽出でき れば，それを逆解析することで，表層地盤の $S$ 波速度 構造が推定できる可能性もある。このような表面波特有 の性質に着目した地盤探查として，地表で強制的にレイ リー波を発生させ，その分散性を観測する方法が従来よ

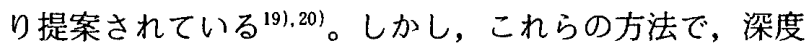
$10 \mathrm{~m}$ より深い地盤構造を決定しようとすれば，重量のあ る振源を用意する必要がある。一方, 短周期微動を積極 的に利用すれば，振源を用意することなしに対応する深 度の $S$ 波速度構造を迅速に推定できる可能性がある。 この点で, 短周期微動を利用した地盤探査は有望と考え られるが，その有効性と適応限界を見極めるためには， さらに観測例の蓄積が必要と思われる。また，図一12 に見られるような分散曲線に含まれる高次モードの影響 を逆解析でどのように評価するかなど，さらに検討を要 する点もある。

\section{6. 結 論}

地盤構造の分かっている2地点で一昼夜にわたる短周 期微動のアレイ観測を行い, 両地点における短周期微動 の基本的特性に関して以下の結論を得た。

1）短周期微動の水平動亡鉛直動のスペクトル振幅およ びその卓越周期に日変化が認められる場合でも, 水平鉛 直振幅比の周期特性およびその比が最大となる周期は日 変化がなく安定している。

2）短周期微動の水平鉛直振幅比の周期特性はレイリー 波の水平鉛直振幅比の周期特性と比較的良く対応してい る。

3）短周期微動の水平鉛直振幅比が最大となる周期は, レイリー波の理論水平鉛直振幅比が最大となる周期およ び $S$ 波重複反射理論から求められる地盤の固有周期に ほぼ対応している。

4）短周期微動の鉛直動に対する $F-K$ スペクトル解析 より,レイリー波のものと考えられる分散特性が求めら れる。この分散特性は微動のパワーが十分ある周波数領 域では日変化がなく安定している。

今後, 周辺環境条件の異なる種々の地盤に対し, 更に, 観測例を蓄積する必要があるものの，以上より，短周期 微動にはレイリー波が含まれており，この特性を抽出す ることで, 振動源の特性を除去して地盤特性を推定でき る可能性が示された。

\section{謝 辞}

本研究に関し, 東京工業大学大学院総合理工学研究科 
翆川三郎助教授には貴重なご意見を賜わった。記して謝

意を表す。

\section{参考文献}

1) Kanai, K. and Tanaka, T. : On mictoremor, VW, Bulletin, Earthquake Research Institute, 39, pp. 97 114, 1961.

2) Udwadia, F.E. and Trifunac, M.D. : Comparison of earthquake and microtremor ground motions in El Centro, California, Bulletin of the Seismological Society of America, Vol.63, No.4, pp.1227-1253, 1973.

3）中村 豊, 上野 真：地表面震動の上下成分と水平成分 を利用した表層地盤特性推定の試み，第 7 回日本地震工 学シンポジウム講演集, pp. 265〜270, 1986.

4) Aki, K. : Space and time spectra of stationary stochastic waves, with special reference to microtremors, Bulletin, Earthquake Research Institute, 35, pp. 415 456, 1957.

5）野越三雄, 五十嵐亮：微動の伝播性, 地震 第 2 輯, 第 23 巻, pp. 264 280, 1970.

6) Asten, M.W. : Geological control on the three-component spectra of Rayleigh-wave microseisms, Bulletin of the Seismological Society of America, Vol.68, No.6, pp. 1623 1636, 1978.

7) Liaw, A. L. and McEvilly, T.V.: Microseisms in geothermal exploration-studies in Grass Valley, Nevada," Geophysics, Vol. 44, No. 6, pp. 1097 1115, 1979.

8) Allam, A. and Shima, E. : An Investigation into the Nature of Microtremors, Bulletin, Earthquake-Research Institute, 45 , pp. $43 \sim 60,1967$.

9）工藤一嘉，太田 裕，後藤典俊，鏡味洋史，塩野計司、 坂㞩直巳, 成瀬聖慈, 出原孝示, 竹内文朗：やや長周期 の微動観測と地震工学への適用 (4)-Array 観測による 微動伝播性の検討一, 地震 第 2 輯, 第 29巻, pp.323 $337,1979$.

10）塩野計司，太田 裕，工藤一嘉：やや長周期の微動観測 と地震工学への適用（6)一微動に含まれる Rayleigh 波 成分一, 地震 第 2 輯, 第 32 巻, pp. 115 124, 1979.

11) Asten, M.W. and Henstridge, J.D. : Array estimator and the use of microseisms for reconnaissance of sedime. ntary basins, Geophysics, Vol.49, No.11, pp.1828 $1837,1984$.

12) Horike, M. : Inversion of phase velocity of long-period microtremors to the $\mathrm{S}$-wave-velocity structure down to the basement in urbanized area," Journal of Phys. Earth., 33, pp. 59 96, 1985.

13）岡田 広, 松島 健：長周期微動の観測による厚い地盤 構造の推定について, 第 7 回日本地震工学シンポジウム 講演集, pp. 211 216, 1986.

14) Tokimatsu, K., Shinzawa, K., Kuwayama, S., and Abe, A. : Estimation of Vs profiles from Rayleigh wave dispersion data at sites affected in the Loma Prieta Earthquake, Proc., Int. Conf. on Seismic Zonation, Vol. 2, pp. 507 514, 1991.

15) Sato, T., Kawase, H., Matsui, M., and Kataoka, S. : Array measurement of high frequency microtremors for underground structure estimation, Proc., Int. Conf. on Seismic Zonation, Vol.2, pp.409 416, 1991.

16) Capon, J. : High-Resolution Frequency-Wave-number Spectrum Analysis, Proc., IEEE, 57, pp. 1408 1418, 1964.

17）小林喜久二：やや長周期微動の基礎的性質と地下構造推 定への応用, 第 17 回地盤振動シンポジウム, 微動の工学 的利用についてーその現状と可能性一, pp. 19〜30, 1989.

18) Haskell, N. A. : The Dispersion of Surface Waves on Multilayered Media, Bulletin of the Seismological Society of America, Vol.43, No.1, pp. 17 34, 1953.

19) Nazarian, S., and Stokoe, K. H., II : In situ shear wave velocity from spectral analyșis of surface waves, Proc., 8 th World Conf. on Earthquake Engineering, Vol. 3, pp. 31 38, 1984.

20) Tokimatsu, K., Kuwayama, S., Tamura, S., and Miyadera, Y. : Vs determination from steady state Rayleigh wave method, Soils and Foundations, Vol.31, No. 2, pp. 153 163, 1991.

(1992 年 3 月 30 日原稿受理, 1992年 6 月 20 日採用决定) 